\title{
CORPORATE STRUCTURE AS ECONOMIC SYSTEM AND OBJECT OF ANALYSIS
}

\author{
Pugacheva M.A. \\ Institute of Management Economics and Finance \\ Kazan Federal University \\ Kazan, Russia
}

Morozova I.G

Kazan Innovative University University named after V.G.

Timiryasov (IEML),

Kazan, Russia

\author{
Kuzmina Z.V., \\ Kazan Innovative University named after V.G. Timiryasov \\ (IEML) \\ Kazan, Russia \\ Girfanova E.Ju \\ Kazan National Research Technological University \\ Kazan, Russia
}

\author{
Tokar V.M \\ Kazan National Research Technological University, \\ Kazan, Russia
}

\begin{abstract}
The development of the economic system of the modern region is determined not only by natural and climatic conditions and resource opportunities, but also by the enterprise and efficiency of corporations, whose management mechanism ensures the realization of the economic potential of the used items and factors of production. The structure of the corporation is built in accordance with the classical understanding of the essence of the economic system; the connected unity of the work of its elements allows obtaining a synergetic effect, a clear hierarchical leadership with the help of appropriate tools, disciplines, organizes and streamlines business processes. In this article, the authors disclose the essence of corporate structures and proposed a new interpretation of their category. Based on the conducted research, the significance of the results of the activity of corporate structures for the social and economic situation of the region is revealed, which consists in ensuring the development of priority areas of its economy; share in the gross regional product, share in total revenues to the regional budget, the number of jobs created, the quality of life of the population of the region, etc.
\end{abstract}

Keywords - region, system, corporation, efficiency, vertically integrated holding, financial and industrial group.

\section{INTRODUCTION}

Disclosure of the concept "system" according to the constructive approach represents: firstly, "the set of the integrated and constantly interdependent or interacting elements formed for achievement of specific goals, at the same time communications between elements are defined and stable, and their productivity or functionality of the system is higher than in the simple sum of elements" [1]; secondly, "the final set of functional elements and communications between them allocated from the environment according to the planned purpose within the set time interval" [18].
Proceeding from definitions, functioning of the system is directed to achieve a specific goal. Integrity, synergism and hierarchy are characteristics of it.

A goal-setting function as a category of management causes the difference of economic systems from the other types of the systems which consists of the subject - the object relations and the mechanism of their regulation in the direction of ensuring production efficiency, distribution, exchange and/or consumption of the economic benefits. The subject structure of the economic system can be presented by economic entities, natural or legal entities, various legal forms, a role and the place in organizational hierarchy, the skill level, education and other characteristics. The object structure enterprises, employees of organizations, resources that will transform to finished goods, the purposes and different institutes. The mechanism of regulation and realization of the specified relations includes functioning of the levers supplementing each other and instruments of influence that provide expanded reproduction of the economic benefits.

Now the economic system can be considered as a unity of the economic benefits of elements that are regularly interacting concerning expanded reproduction as a part of subjects, objects and the corresponding mechanism.

\section{CORPORATE STRUCTURE AS ECONOMIC SYSTEM AND SUBJECT OF ANALYSIS}

In explanatory dictionaries and scientific and economic literature, a concept "corporation" is treated ambiguously. On the one hand, the concept "corporation" is defined as any association having economic targets of activity [5]. On the other hand, the legal entity which is association of natural 
persons; however at the same time, it independently functions as "one of forms of monopolistic associations" [4, page 11].

The main objective of a corporation is maximizing profit by means of the most rational and effective usage of resources, production expansion of the range that exerts considerable impact on acceleration of social and economic development of the region.

In addition, the purposes of creation of a corporation are:

- protection against undesirable absorption;

- protection of the share of the market and gaining the new markets;

- combination of efforts of joint scientific developments, investment projects, creation of new types of production;

- increase in financial opportunities;

- activity diversification;

- ensuring financial stability and competitiveness;

- increase in management efficiency, etc.

But at the same time, very often, corporate structures, receiving various benefits, are focused on short-term objectives that is confirmed by extensive operation of the resource base without search for innovative ways of the development.

The main signs of a corporation:

- legal entity;

- limited liability;

- free sale of shares;

-centralized management of the Board of directors.

Thus, the corporation represents a public legal entity bearing limited liability according to obligations of the organizations which are its part under the direction of a central office of the management [7, page 7]. Activity of the corporation is focused on obtaining a positive result, its formation is carried out by analogy of creation of an economic system, which connected unity of the work of elements allows one to gain synergetic effect, and the accurate hierarchical management by means of the corresponding tools disciplines systematizes and orders business processes. So, the corporation at the same time acts as an economic system on the microlevel and an element of an economic system on meso - and macrolevels, results of its activity need to be subjected to the analysis and assessment. As the element of the regional economic system, it functions under the terms and according to the rules set by the latter; as the economic system it is focused on realization of the model of a state planned economy in the conditions of the market when managers of corporations, predicting tendencies of development of the external environment, develop an indicative model of the life.

Legal entities treat corporations (corporate structures) according to Art. 65.1 of the Civil code of the Russian Federation, founders (participants) of which form their supreme body and have the right to participate (membership) in them.

In economic literatures the group of corporations is given by economic and organizational criteria. Depending on a way of the organization and management, researcher V.A. Laptev points out horizontal, vertical and mixed corporations. Emergence of horizontal type of associations happens under signing of the contract of a joint venture, according to which two and more business agents having the equal rights unite in order to achieve the planned purposes (increases arrived, consolidations of competitiveness, etc.).

The following groups relate to enterprise associations of vertical type:

1) holdings, the part of which are the dependent and affiliated undertakings, submitting to the head holding company;

2) financial and industrial groups which are created according to the contract on formation of financial and industrial groups or in the form of the integrated holding of vertical type in both cases by the run head holding company.

Executive bodies of the participants in the specified forms of enterprise associations do not consist in direct submission to executive bodies of the head holding company.

In the primary branches of the industry one can meet most often the enterprise associations of the mixed type where two and more holdings are integrated according to the simple partnership agreement, forming thereby large corporations as a part of the enterprises and managements with the elements of horizontal and vertical structures.

Depending on existence of the consent of the business agents for participation in enterprise associations voluntary and compulsory allocate associations. The first of them are, as a rule, formed on the basis of signing of the contracts (agreements) between participants of association, the second by acquisition of shares of the authorized capitals of the affiliated organizations by the holding company or realization of a possibility of the holding company to define the decisions made by subsidiaries.

Based on obligatory registration, it is accepted to allocate enterprise associations that are subject to registration (with obtaining the appropriate registration number) and are not subject to registration. Financial and industrial groups are subject to registration without fail.

The financial and industrial group is created from the moment of its state registration (Art. 5 of the Law on FPG). Other enterprise associations, in particular, the associations created based on the simple partnership agreement and holdings during creation are exempted from the procedure of the state registration. In this case it is only about indirect state registration of enterprise associations (for example, holding) which constituent has documents of the enterprises and (or) issues of their actions where extent of participation is reflected [13, page 26] and, consequently, the definition of decisions of subsidiaries of the holding registers in corresponding public authorities. 
The complexity of the structure and scales of activity of enterprise associations define a possibility of their classification by territorial sign: "those which are formed within one state, and those which are settled down in the territory of various states (transnational and interstate associations)" [13, page 27].

Also according to the territorial sign, corporate structures can be divided into several groups:

1. The international, or transnational, corporate structures that are among their participants are available legal entities registered in the territory of other states or there are isolated structures in the territory of other states.

2. Interregional corporate structures in which the enterprises of various regions are connected among themselves by production cooperation interact.

3. Regional corporate structures in which the industrial enterprises are technologically connected among themselves and the financial organizations are located at the same place.

Based on dependence of enterprise associations on branch accessory, they are divided into branch (innovative, insurance, investment metallurgical, etc.) and interindustry (oil and gas, bank, insurance and investment activity and others).

The target reference point of activity of corporate structures establishes allocation of the enterprises based on:

1) achievements of economic domination in the market;

2) maximizing (profit-maximization);

3) strengthening of the competitiveness of business agents;

4) advances of concrete production (goods, works and services) in the corresponding market.

The most popular group in Russia is the group of enterprise associations according to legal forms reflecting the legal structure of the enterprise and management of association and relationship between its participants. According to these criteria there are:

$\square$ holdings;

$\square$ financial and industrial groups;

$\square$ joint venture.

In the legislation of Russia still there is no accurate definition of a concept "holding". The only information is in the bill on holdings, in the edition of the special commission: "the holding is a set of two or more legal entities (participants of holding) connected by the relations (the holding relations), the decisions allowing one of them (the head company) to define, made by other participants" [16]. On the basis of the definition given in the bill on holdings, it is possible to allocate only two main signs:

1) management and control by the holding head company of dependent and affiliated undertakings;

2) the economic independence of participants of holding which is not connected with activity of holding.
However, there is restriction concerning the structure of the holding only by legal entities, and absence of quantitative indicators that characterize activity of holding following from this definition.

The review of scientific literature in the field of the enterprise right has revealed existence of various definitions of a concept "holding". So, K.Ya. Portna understands a group of persons, the head company and other economic societies as a holding, concerning the holding head company, and defines the decisions made by them [15, page 12].

At the same time, such domestic scientists as Yu. Vinslav recognize a holding as the merging of the legal entities which consist of the main and affiliated the organizations, in common carrying out financial, production, trade and other commercial activity and interconnected with each other by the system of participation of both property, and non-property character granting the right of the main company to resolve the major administrative and economic issues concerning the activity of the affiliated organizations [6, page 21].

Researcher I.S. Shitkina in her works adheres to the following interpretation: "The holding is a form of enterprise association which represents a group of companies (participants), formed by communications of economic dependence and control, which participants, despite formal legal independence in the economic activity, are under supervision of one of the participants of the group - the head holding company which is the center of association owing to possession in authorized capital of the prevailing shares or other circumstances directly or indirectly influences decisionmaking of other participants of the group" [21, page 50].

More complete definition of a concept "holding" including a feature set and describing its essence and the legal nature is given in works of researcher V.A. Laptev. Proceeding from the definition, it is possible to specify the following as the main signs of holding:

- the head holding ("parent") company is a basic element in the structure of holding;

- the head company is governing the body of the management of the enterprise association and executes individual share in the capital dependent and subsidiaries;

- the enterprises which are a part of holding despite legal independence conduct the uniform economic policy.

In the Russian legislation, in particular the Federal law of 30.11.1995, No. 190-FZ, "About financial and industrial groups" concerning financial and industrial groups", the following definition of Financial and industrial group is registered: "a set of the legal entities acting as the basic and subsidiaries, or as a whole or in part merged material and intangible assets (the system of participation) on the basis of the contract in creation of the financial and industrial group for technological or economic integration for implementation of the investment and other projects and programs directed to increase the competitiveness and to expand the sales markets of goods and services, to increase the production efficiency, to create new jobs" (Art. 2). 
Here it should be noted that there is lack of clearness in determination of criteria and restrictions during creation and functioning of financial and industrial groups. So, on the one hand, admissible change in the sizes of the enterprises making the financial and industrial group is not specified; but there is no hint for ensuring the complete understood public policy in spheres of activity and development of financial and industrial groups and national economy.

In the monographic researches of the authors similar to the legislation, there are bottlenecks consisting in lack of the full list of signs which defines a reality with reference to enterprise associations, which are also characteristic for the financial and industrial group. Often the term FPG is understood as any form concerning steady cooperation and interpenetration of the financial (bank) and industrial capitals. So for example, researcher V.A. Tsvetkov defines the financial and industrial group as a financial and industrial complex, within which an integration of the monetary institutions with the industrial enterprises on the basis of definition of the relations between them, regarding financial and economic interdependence, labor division and its coordination for execution of economic activity, is carried out. Similar to this definition, B.V. Milner specifies in his works that "FPG is the diversified multipurpose structure created by the association of the capitals of credit and financial and investment institutes, enterprises and other organizations to increase its profit, consolidation of competitiveness in the external and internal markets, increase its efficiency of production and financial transactions, strengthening of cooperation and technological communications, growth of an economic possibility of participants" [14].

A.E. Dvoretskaya and Yu.B. Nikolsky unlike other authors place emphasis on voluntariness of the entry of enterprises and organizations into FPG and find it as a structure which "allows one to concentrate financial resources for carrying out investments into the industry and to maximize the consolidated profit of all participants of the group" [10], comparing activity of FPG to functions of the commercial bank.

The opinion of researcher M. Eskindarov, who notes that "process of incorporating is the key characteristic of FPG, which provides association of material and intangible assets of the enterprise, is interesting. At the same time, any form of integration of the enterprises means association of intangible and material assets; and incorporating is the main characteristic of a concept "corporation"" [10].

M. Eskindarov together with I. Belyaeva specify in the work that "the macrostructure is the most general concept of the financial and industrial group which main types are multinational corporations (multinational corporation), cartels, FPG, conglomerates and consortia. FPG according to these authors has the highest level of the internal organization and unlike multinational corporations conducts a uniform investment policy, including such signs as internal distribution of financial resources and presence of the internal competition" [10].

Broad interpretation of contents of financial and industrial groups is also a characteristic of the definition of researcher I.
Bunin, who is defining FPG as a form of rather stable cooperation and interpenetration of the financial and industrial capital.

The position of researcher V.E. Dementiev who, on the one hand, defines FPG as a form of integration of financial and industrial structures, meeting the criteria enshrined in corresponding acts, and followed by official recognition, and inclusion in the Register of financial and industrial groups of the Russian Federation is similar; on the other hand, as a form of rather stable cooperation and interpenetration of the financial and industrial capital [11]. The first definition of FPG given by the author found the continuation in the works of researchers M.A. Ilyin and A.V. Tikhonov [12] who have revealed its essence through a legislative basis of the fact of FPG existence. From our point of view, the research potential of the specified concept is exhausted while the task of the researcher consists just in revealing the essence and an economic content of the phenomenon for establishment and fixing on the legislative level of optimum and economically rational forms of its life.

Thus, the considered definitions reveal the main characteristics of FPG, first, as "presence of the financial and industrial capital, though for example, in Russia, among the first it was registered by several FPG consisting of agricultural and trade enterprises" [3]; second, a target reference point of activity of FPG in the direction of "strengthening of competitiveness in the markets increases in efficiency of production and financial transactions, consolidations of technological and cooperation communications, growth of the economic potential of participants" [3] and so forth; third, as a basis of their education, incorporating is considered.

Stating the aforesaid, the definition of a concept "financial and industrial group" given by researcher A.Ya. Butyrkin seems to be correct. The author analyzes the financial and industrial group "the large diversified economic structure of corporate type which is carrying out the activity in the field of agricultural, industrial production and trade which has stable communications with a commercial bank based on the economic and financial interdependence which is often supported on the level of the share capital, which main characteristic is existence of the centralized management" [3].

The offered group of enterprise structures is presented in Fig. 1.

The most significant sector for the modern economy of Russia, including the Republics of Tatarstan and Bashkortostan, is the oil sector as a part of which the vertically integrated oil companies, (VIOC) which are steadily holding a high share of a gross product in Russia and regions, dominate. Creation of the vertically integrated oil companies happened in the early nineties and is connected with the privatization period. Despite the existing differences (for example, the form of ownership, structure, etc.), a uniform sign of the vertically integrated oil companies is the possibility of association of all links of a technological chain, from extraction of raw materials before release of the finished production of high extent of processing. About $90 \%$ of volume of diesel fuel is produced in the oil processing enterprises which are a part of vertically integrated holdings. 
Existence of corporate structures is characteristic of the most part of regions of Russia. At the same time there is a tendency of registration of their head holding companies in the Central region of the Russian Federation (more than $48,5 \%$ of total of the registered FPG), including about $37,5 \%$ in Moscow. For comparison, in the Northwest region 7\% (from them $4 \%$ in St. Petersburg) and in the Ural region - about $11 \%$ is registered [20].

The feature of the Republic of Tatarstan is that most of the corporations functioning in its territory are regional and registered in the republic, and it is a big advantage for its economy.

Entry of the enterprises of the region into the structure of corporations induces the need of regular mutual contacts between their management and the local administration. In the organization of these relations it is necessary to consider how reorganization of the enterprise will be reflected on a population level of living; as far as control over the enterprise will remain; readiness of the financial organizations (banks, insurance and investment companies) with a corporate structure to carry out investments in this territory and to provide financial aid to regional authorities and also determination of the sizes of the tax concessions by regional authorities.

It should be noted that the twentieth century is recognized as a century of large corporations which activity "became a major factor of the European, Japanese and American economies which provided competitiveness" [3] in the form of the essential growth of volume of gross domestic product, high-quality development of the production and technological capital and also improvement of conditions and content of formation and realization of the human capital.The main advantage of large-scale production is realization of potential of effect of synergy and the scale at which the sum of volumes of the accumulated resources brings a bigger return, than its parts separately, and along with it great opportunities in the sphere innovative and investment and activity; the authority of the large producer which is able to provide solid mortgage providing at external loans, cross financing of non-profitable segments of activity, etc.

As the element of economic system activity of the corporation "raises stability of real production sector of the region, provides optimization of financial and material flows, coordination of the internal prices, facilitates fight for foreign markets; provides reduction of financial risks and the need for current assets, orders interaction of economic agents" [3] on the basis of cooperation and specialization; defines reduction of a share of a public sector in economy. Influence of the corporate structures in the economic system of the region is caused by increase in volume and quality of a gross regional product, increase in tax revenues in budgets of the federal and regional level, providing the region with jobs of assigned amount and quality, specific weight of innovative production in VRP, the level of income of the population of the region and quality of his life.
The Republic of Tatarstan which is a part of the Volga Federal District is one of the regions of Russia which are the most economically developed ones. It possesses rich natural resources, the developed industry, the high intellectual potential and qualified labor. The most dominating branches in RT are production and oil refining and also mechanical engineering.

The first oil in Tatarstan was extracted in May, 1944, in this connection the Tatneft company was created; then the enterprises of petrochemistry, a tire plant were constructed and the mechanical engineering began to develop. And as the Soviet economy had the centralized management, all the earned means went to "center", and Tatarstan remained the republic with the backward infrastructure.

The Republic of Tatarstan received surge in the development at the beginning of 1990, after adoption of the Declaration on sovereignty on August 30, 1990. And a part of powers and transfer of a part of the taxes in the limits needed for their execution was delegated by the contract "About Differentiation of Areas of Jurisdiction and Mutual Delegation of Powers between Public Authorities of the Russian Federation and Public Authorities of the Republic of Tatarstan" signed in February, 1994.

This time Tatarstan began to be integrated into world economy, debugging the mechanism of international backgrounds. In a situation of a rupture of economic relations between regions and business, partners' independent entry of oil industry workers of Tatarstan into the world market provided the population of the republic with goods of consumption, allowed one to buy the equipment and technologies for the industry. Earned currency in the 1990s allowed one to avoid the social tension in the republic.

Without wishing to be limited to raw materials export, the republic in the late nineties headed for creation and development of oil processing productions that promoted active formation of enterprise associations. Development of the Tatarstan corporations was characterized by activity of the processes of consolidation and division of assets. The greatest number of their creation falls to 2000 - 2005 (Tatneft and TAIF group of companies).

Social and economic development of the Republic of Tatarstan depends on results of the activity of the corporations which are on its territory from now on. This interrelation occurs through investment and innovative components, support of the social sphere of the region, payment for use of resources and infrastructure of the region.

According to the rating assessment of the economic and social situation of regions as a part of Volga federal district constructed by experts of Rating agency "RIA Rating", the Republic of Tatarstan for the last four years has held a position of the leader [17]. 


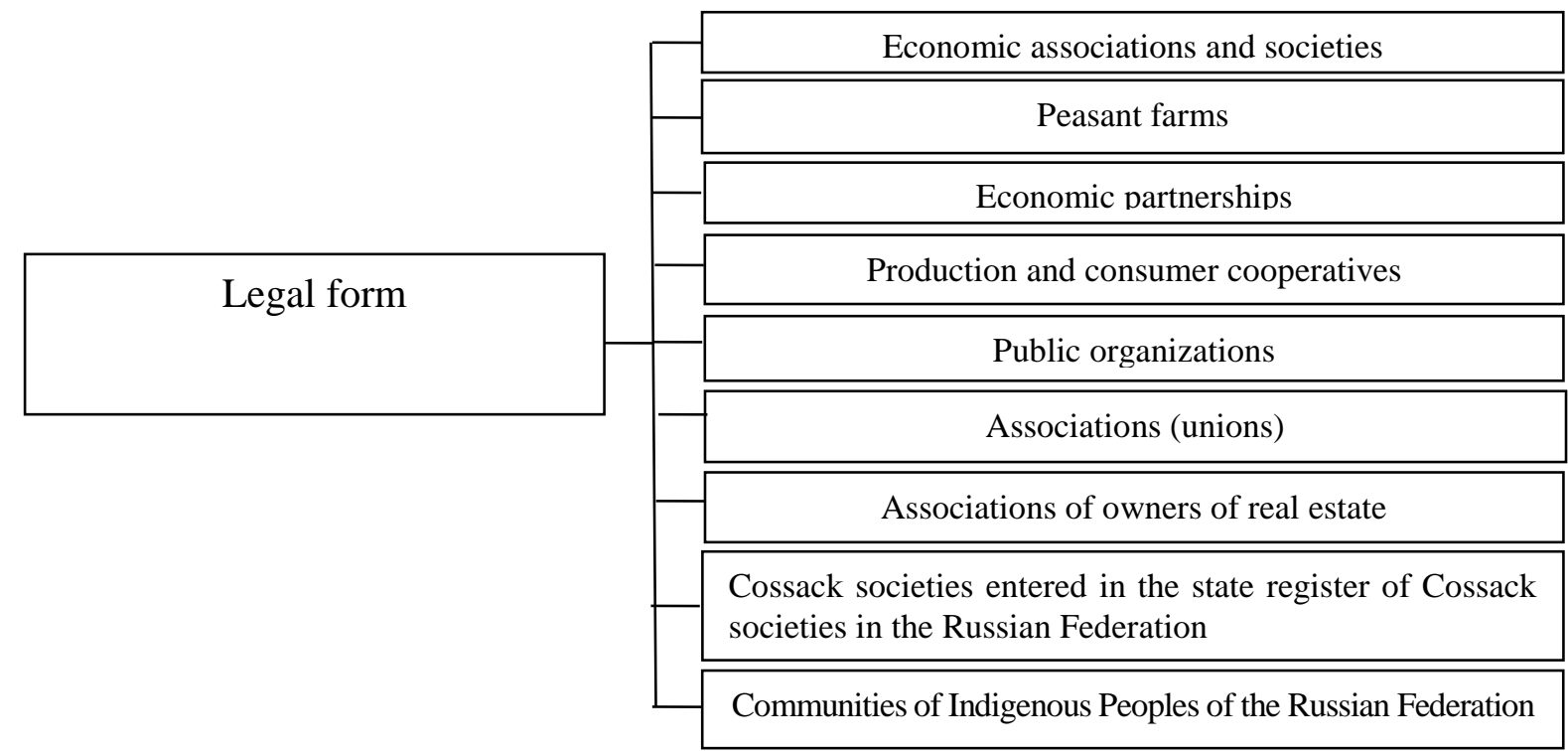

\begin{tabular}{|l|l|}
\hline By the method of association & Holding company \\
\cline { 2 - 3 } & Financial and industrial group \\
\hline
\end{tabular}

\begin{tabular}{|c|} 
By the way of organization and \\
management
\end{tabular}

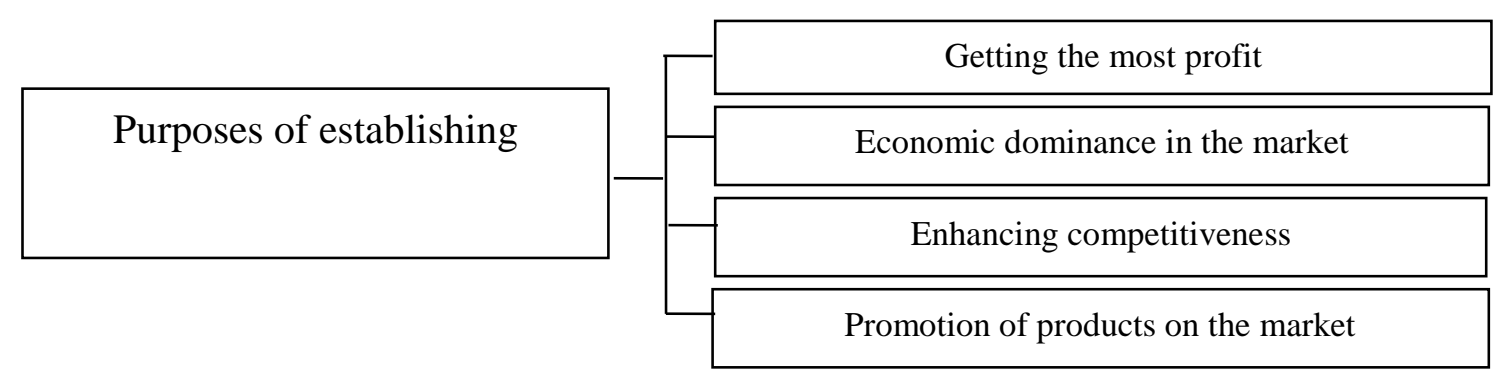

Branch accessory

Form of ownership

Fig. 1. Grouping of business associations 
TABLE I. RATING OF SOCIALLY ECONOMIC SITUATION OF REGIONS AS PART OF VOLGA FEDERAL DISTRICT

\begin{tabular}{|l|c|c|c|c|}
\hline $\begin{array}{c}\text { Structure of Volga federal } \\
\text { district }\end{array}$ & $\mathbf{2 0 1 3}$ & $\mathbf{2 0 1 4}$ & $\mathbf{2 0 1 5}$ & $\mathbf{2 0 1 6}$ \\
\hline Republic of Bashkortostan & 4 & 3 & 2 & 2 \\
\hline Kirov Region & 12 & 11 & 9 & 12 \\
\hline MariEl Republic & 14 & 14 & 14 & 14 \\
\hline Republic of Mordovia & 13 & 13 & 13 & 13 \\
\hline Nizhny Novgorod Region & 5 & 5 & 5 & 5 \\
\hline Orenburg Region & 6 & 6 & 6 & 6 \\
\hline Penza Region & 11 & 10 & 11 & 11 \\
\hline Perm Region & 3 & 4 & 3 & 4 \\
\hline Samara Region & 2 & 2 & 4 & 3 \\
\hline Saratov Region & 7 & 7 & 8 & 7 \\
\hline Republic of Tatarstan & 1 & 1 & 1 & 1 \\
\hline Udmurt Republic & 8 & 8 & 7 & 8 \\
\hline Ulyanovsk Region & 9 & 9 & 12 & 10 \\
\hline Chuvash Republic & 10 & 12 & 10 & 9 \\
\hline
\end{tabular}

The rating of the region is influenced in turn by productive and economic activity of corporate structures which results provide a considerable part of budget revenues of the region, determine the investment potential and innovative activity, create prerequisites for development of a production and social infrastructure.

In the Republic of Tatarstan as of 1.01.2016, more than 12,0 thousand industrial enterprises carry out the activity, 100 of them belong to large-scale corporations, and define $80 \%$ of production of VRP [7]. More than $60 \%$ of industrial output of Tatarstan provided six of its corporations: JSC Tatnefteproduct, JSC Sheshmaoil, JSC Tatenergo, PJSC Tatneft, JSC TAIF, JSC Ak Bars Holding Company, most of which are in the mixed property. [8]

In the course of the economic activity of corporate structures in the republic, the goods and services providing growth of welfare of the population are created, for what an essential part of its resource potential is used.

Counter influence of the economic system of the region is shown at the realized institutes opening investment, innovative, tax and budgetary policy, policy in the field of professional education and resource base, trade, bank, engineering and communication, transport and other infrastructures.

\section{CONCLUSION}

Thus, the power of the region and the country is defined in general by large-scale enterprise associations. Despite development of small and medium business, in the last years, large corporate structures created by the diversified principle are the main engine of the dynamic growth of the national economy and its regions. Therefore, the solution of large-scale tasks which face Russia concerning protection of national interests in the conditions of the global world and consolidation of competitiveness of production of priority branches in the world market causes the necessity of existence in the managing community of the state of the integrated corporate structures providing strategic development in various organizational forms

\section{References}

[1] V.K. Batovrin, Tolkovyj slovar' posistemnoj i programmnoj inzhenerii, M.: DMK Press, 2012.

[2] I.Ju. Beljaeva, M.A. Jeskindarov, Kapital finansovo-promyshlennyh korporativnyh struktur: teorija i praktika, Finansovaja akademija pri Pravitele'stve RF, 1998

[3] A.Ja. Butyrkin, Mehanizmy formirovanija strategi jrazvitija integrirovannyh korporativnyh struktur v promyshlennosti: Diss. ...drajekon. Nauk, 2006.

[4] Z.V. Vdovenko, I.A. Andreeva, Osobennosti metodologii upravlenija korporativnymi strukturami v sovremennom obshhestve, Menedzhment v Rossii i zarubezhom, 2008, № 6, pp. 11 .

[5] Vikipedija. Retrieved from: https://ru.wikipedia.org

[6] Ju.B. Vinslav, I.E. Germanova, Holdingovye otnoshenija i pravoobespechenie ih stanovlenija v Rossii SNG (variant soderzhanija model'nogo zakona o holdingah i kommentarij k nemu), Rossijskij ekonomicheskij zhurnal, 2001, №4, pp. 21.

[7] Gazizova E. U jekonomiki Tatarstana bol'shoj zapas prochnosti Retrieved from: http://expertrt.ru>tema/item/219. schastlivy...svoemu.html

[8] G.K. Gabdullina, Razvitie metodiki ekonomicheskogo analiza i ocenki funkcionirovanija korporativnyh struktur regiona: monografija, Novosibirsk, Izdatel'stvo CRNS, 2017.

[9] G.K. Gabdullina, Sovershenstvovanie mehanizma ocenki dejatel'nosti korporativnyh struktur $\mathrm{v}$ regione, Problemy sovremennoj ekonomiki, 2016, №2, pp. 162-166.

[10] A.E. Dvoreckaja, Ju.B. Nikol'skij, Finansovo-promyshlennye gruppy: menedzhment finansy, Moscow, PRINTLAJN, 1995

[11] V.E. Dement'ev, Finansovye i imushhestvennye osnovanija strategicheskih preimushhestv FPG, Moscow, CJeMI RAN, 1998.

[12] M.A. Il'in, A.V. Tihonov, Finansovo-promyshlennaja integracijai korporativnye struktury: mirovoj opyt i realii Rossii, Moscow, Al'pina Publisher, 2002.

[13] V.A. Laptev, Predprinimatel'skie obedinenija: holdingi, finansovopromyshlennye gruppy, tovarishhestvam, M.: Volters-Kluver, 2008.

[14] B.Z. Mil'ner, Krupnyekorporacii - osnova podema i uskorennogo razvitijaj ekonomiki, Voprosy ekonomiki, 1998, №9, pp. 66-76.

[15] K.Ja. Portnoj, Pravovoe polozhenie holdingov v Rossii, Nauchnoprakticheskoe posobie, Moscow, VoltersKluver, 2004.

[16] The Federal Law draft about the holding companies No. 99049555-2. Retrieved from: http://www.consultant.ru/cons/cgi/online.cgi?req=doc;base=PRJ;n=1333

[17] Rejtingsubektov RF poitogam 2012-2015 gg. Retrieved from: ria.ru>INFOgrafika>20150616/1061393359.html

[18] V.N. Sagatovskij, Osnovy sistematizacii vseobshhih kategorij, Tomsk, 1973. Retrieved from: https://ru.wikipedia.org

[19] The federal law of 30.11.1995 No. 190-FZ "About financial and industrial groups" Retrieved http://www.consultant.ru/document/cons_doc_LAW_8476/

[20] V.A. Cvetkov, Sovremennoe sostojanie i perspektivy razvitija finansovo-promyshlennyh grupp RF. Retrieved from: http://www.iprras.ru/articles/analysis.htm

[21] I.S. Shitkina, Holdingi: pravovoe regulirovanie i korporativnoe upravlenie, M.: VoltersKluver, 2006. 